CROSSING BORDERS, REINFORCING BORDERS 


\section{Inter-America Series}

Edited by Duncan Earle and John Peterson

In the new "Inter-American" epoch to come, our borderland zones may expand well past the confines of geopolitical lines. Social knowledge of these dynamic interfaces offers rich insights into the pressing and complex issues that affect both the borderlands and beyond. The Inter-America Series comprises a wide interdisciplinary range of cutting-edge books that explicitly or implicitly enlist border issues to discuss larger concepts, perspectives, and theories from the "borderland" vantage and will be appropriate for the classroom, the library, and the wider reading public. 
SOCIAL

CATEGORIES,

METAPHORS,

AND NARRATIVE

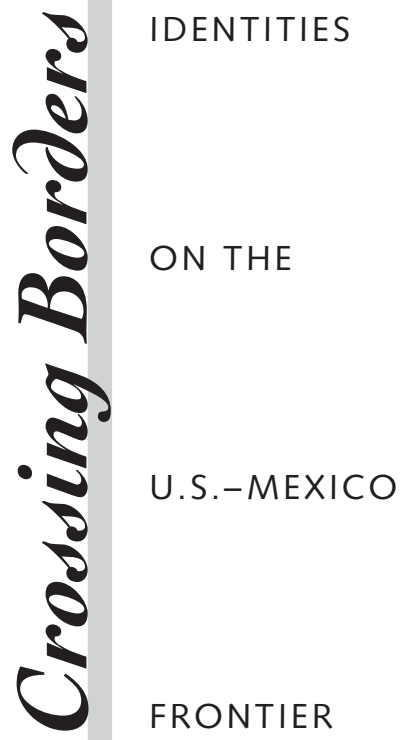

REINFORCING BORDERS

PABLO VILA 
Copyright (c) 2000 by the University of Texas Press

All rights reserved

Printed in the United States of America

First edition, 2000

Requests for permission to reproduce material from this work should be sent to Permissions, University of Texas Press, Box 7819, Austin, TX 78713-7819.

(0) The paper used in this book meets the minimum requirements of ANSI/NISO Z39.48-1992 (R1997) (Permanence of Paper).

Library of Congress Cataloging-in-Publication Data

Vila, Pablo, date

Crossing borders, reinforcing borders : social categories, metaphors, and narrative identities on the U.S.-Mexico frontier / Pablo Vila. - 1st ed. p. cm. - (Inter-America series)

Includes bibliographical references and index.

ISBN 0-292-78739-1 (hardcover : alk. paper) -

ISBN 0-292-78740-5 (pbk. : alk. paper)

1. Ciudad Juárez (Mexico) - Social conditions. 2. El Paso (Texas) - Social conditions. 3. Mexican-American Border RegionSocial conditions. 4. Group identity - Mexico - Ciudad Juárez.

5. Group identity - Texas-El Paso. 6. Group identity-MexicanAmerican Border Region. I. Title. II. Series.

HN120.C48.V54 2000

$306^{\prime} .0972^{\prime} 16-\mathrm{dc} 21$ 